\title{
Evaluation of Echocardiographic Findings in Type II DM of North Indian Patients with or Without Cardiac Disease
}

\author{
Authors \\ Rajendra Kumar Verma ${ }^{1}$, Shivendra Verma ${ }^{2}$, Richa Giri ${ }^{3}$, Vimlesh $^{4}$, Nirmala Singh $^{5}$ \\ ${ }^{1}$ Department of Internal Medicine, GSVM Medical College, Kanpur, India- 208002 \\ Email: rkv45anand@gmail.com \\ ${ }^{2}$ Department of Internal Medicine, GSVM Medical College, Kanpur, India- 208002 \\ Email:dr.shivendra@gmail.com \\ ${ }^{3}$ Department of Internal Medicine, GSVM Medical College, Kanpur, India- 208002 \\ Email: richa227@rediffmail.com \\ ${ }^{4}$ Department of Internal Medicine, GSVM Medical College, Kanpur, India- 208002 \\ Email:drvimlesh1987@yahoo.com \\ ${ }^{5}$ Clinical Practitioner, Pediatrics, Naman clinic, Kanpur, India- 208002 \\ Email:nirmal214singh@yahoo.com
}

\begin{abstract}
The objective of our study was to determine whether there is statistically significant association between diastolic dysfunction in the asymptomatic and symptomatic (cardiac disease) subjects with type 2 diabetes mellitus and its relation to age, duration of DM, HbAlc, blood pressure, microalbuminuria and e GFR. In this cross-sectional study 90 subjects with type 2 diabetes were categorize in two groups after appropriate inclusion and exclusion criteria. Statistical analysis was done using SPSS 17.0. From this study we conclude that patients of type 2 diabetes mellitus without cardiac disease (asymptomatic) do have left ventricular diastolic dysfunction as well as left ventricular systolic dysfunction and this dysfunction increases with duration of diabetes mellitus, higher blood pressure, higher Hbalc levels and presence of albuminuria but has no significant correlation with eGFR. Strict watch and control of these parameters will help to delay the onset of cardiac disease in asymptomatic patients of type 2 diabetes mellitus.
\end{abstract}

Keywords- Type 2 Diabetes mellitus, Diastolic dysfunction, Systolic dysfunction, Hbalc, microalbuminuria, eGFR.

\section{INTRODUCTION}

Diabetes, an important metabolic disorder worldwide is classified as type 1 and type 2 diabetes, the former associated with insufficient insulin secretion from the beta cells in the pancreas, and the latter characterized by the phenomenon of insulin resistance with relative insulin deficiency Type 2 diabetes mellitus is a leading cause of morbidity and mortality. Cardiovascular complications are known to be the main cause of death and morbidity in diabetic patients, as over $75 \%$ of all diabetic patients die from cardiovascular events ${ }^{1}$ However, microvascular complications, such as kidney disease and retinopathy, are frequent and contribute to the total disease burden. The microvascular and macrovascular complications of diabetes are mediated primarily by atherosclerosis. Hyperglycemia causes vascular disturbances, especially endothelial dysfunction, contributed by 
abnormal nitric oxide biology, increased endothelin and angiotensin 2, and reduced prostacyclin activity $^{2}$. Diabetic dyslipidemia further contributes to the increased atherosclerotic risk. It is mainly due to increased low density lipoproteins (LDL), increased apolipoprotein B concentration, increased triglycerides and decreased high density lipoproteins $(\mathrm{HDL})^{3}$ The vascular effects of Advanced Glycosylation End Products (AGE s), circulating free fatty acids aggravate the systemic inflammation due to oxidative stress ${ }^{4}$. Diabetes leads to a prothrombotic milieu ${ }^{5}$ with disturbances in platelet activation and aggregation, thus accelerating atherosclerosis.

As early as 1883, it was thought that patients of diabetes have increased incidence of heart Disease. Later studies confirmed these views. To date diabetes ranks as the 7th leading cause of death in western world (CDC, 1988). Heart involvement in Diabetes is as follows:

- Increased incidence \& severity of atherosclerotic coronary artery disease.

- Cardiomyopathy.

- Autonomic dysfunction involving heart.

- Subclinical cardiac dysfunction.

Hypertension and coronary artery disease, known comorbidities of diabetes, are established causes of heart failure. The most prominent risk factor for heart failure in diabetic patients is prior history of coronary artery disease. Furthermore, heart failure is more frequent in diabetic than in non-diabetic patients with myocardial ischemic injury ${ }^{6}$. Accumulating data from experimental, pathological, epidemiological and clinical studies have shown that diabetes causes changes within the cardiac structure and function, in the absence of coronary atherosclerosis, hypertension or any other known cardiac disease. However, the coexistence of myocardial ischemia, hypertension, and a specific diabetic cardiomyopathy seems to be independent but contributes to the biochemical, anatomic, and functional alterations in cardiac cells and tissues that impair cardiac function. Factors that can cause microvascular abnormalities, endothelial dysfunction, derangement of myocardial metabolism and autonomic neuropathy, such as hyperglycemia, hypertriglyceridemia and hypertension are postulated as etiological factors ${ }^{7,8-10}$.

Over the last three decades, a number of epidemiological, clinical and autopsy studies have proposed the presence of diabetic heart disease as a distinct clinical entity (Rubler et al. ${ }^{11}$, 1972, Fein ${ }^{12}$ , 1985,). Diastolic heart failure (HF) is also referred to as HF, with preserved left ventricular systolic function. Several Studies have reported a high prevalence of diastolic dysfunction among asymptomatic subjects with $\mathrm{DM}^{13}$. The evidence indicates that myocardial damage in diabetic subjects affects diastolic function before the systolic function. The most important mechanisms of diabetic cardiomyopathy are metabolic disturbances (increased free fatty acids, carnitine deficiency, changes in calcium homeostasis), myocardial fibrosis (increases in angiotensin II, IGF-I, and inflammatory cytokines), small vessel disease (microangiopathy, impaired coronary flow reserve, and endothelial dysfunction), cardiac autonomic neuropathy (denervation and alterations in myocardial catecholamine levels), and insulin resistance (hyperinsulinemia and reduced insulin sensitivity) ${ }^{19}$.

Left ventricular diastolic dysfunction represent the reversible first stage of diabetic cardiomyopathy, reinforcing the importance of early examination of diastolic ventricular function in individuals with diabetes. According to Virendra C. Patil study overall prevalence of diastolic dysfunction was $54.33 \%$ in asymptomatic type 2 DM subjects. Similarly Nikhil M Dikshit et al concluded that diastolic dysfunction in patients of diabetes is present in $66 \%$ of patients even when diabetes is present at a younger age, and is of a shorter duration. So far, very few population-based studies have been carried out in North India.

The objective of our study was to determine whether there is statistically significant association between diastolic dysfunction in the asymptomatic and symptomatic (cardiac disease) subjects with type 2 diabetes mellitus and its relation to age, duration of $\mathrm{DM}, \mathrm{HbA1c}$, blood pressure, microalbuminuria and $\mathrm{e}$ GFR. 


\section{MATERIAL \& METHODS}

A cross- sectional study of ninety subjects with type II diabetes mellitus as classified by WHO criteria(1985), attending the General Medicine OPDs, Diabetes Clinic, Medical Wards of the LLR Hospital associated hospitals, GSVM Medical College Kanpur from Jan. 2014 to June 2015 were included in the study. Follow up patients of categorical Diabetes Mellitus were also included in the study. Other patients were subjected to random blood glucose examination and those who had abnormal random blood glucose levels were subjected to oral glucose tolerance test; $75 \mathrm{~g}$ of glucose was given to these subjects after an overnight fast and then fasting and postprandial venous plasma glucose concentrations were measured by the glucose oxidase method.

\section{Criteria for Diabetaes Mellitus Type-2:}

Fasting plasma sugar $>126 \mathrm{mg} / \mathrm{dl}$ on two separate occasions, Post Prandial Plasma $>200 \mathrm{mg} / \mathrm{dl}$ on two separate occasions and HbA1C level >6.5.

\section{Selection Criteria:}

Group A: Patients of Type-2 Diabetes Mellitus with signs and symptoms of Cardiac disease. $(\mathrm{n}=30)$

Group B: Patients of Type-2 Diabetes Mellitus without signs and symptoms of Cardiac disease. $(n=60)$.

\section{Exclusion Criteria:}

1. Patients of type I Diabetes Mellitus.

2. Patients with diabetic end stage renal disease

3. Patients with rheumatic, valvular Heart disease

4. Patients with pregnancy, UTI and any other condition causing proteinuria

5. Patients with congenital heart disease.

\section{Methods}

A detail clinical history of patients was recorded and thorough physical examination including blood pressure was done by an experienced physician.

\section{PLAN OF INVESTIGATIONS}

Routine investigations including: $\mathrm{Hb} \%$, TLC, DLC, ESR, GBP, Serum creatinine, e GFR, Urine routine and microscopy and urine for albuminuria. Specific Investigations: X-ray Chest PA View, 12 Lead Standard Electrocardiogram, Measurement of HbA1C level and fasting lipid profile.

Examination of Fundi Oculi
Echocardiography- It was performed at LPS Institute of Cardiology using Hewlett Packard Ultrasound imaging system (Model 7700 AC) using 3.5/2.5 $\mathrm{MHz}$ phase array transducer. Appropriate precautions were taken to maintain accuracy of imaging. Subjects were examined in the left lateral decubitus and supine position using standard parasternal long axis, short axis and apical views. All recordings and measurements were obtained by the same observer according to the recommendations of the American Society of Echocardiography4 and were always performed at midday to avoid the influence of circadian rhythm on left ventricular diastolic function. Pulsed-wave Doppler (PWD)derived transmitral inflow velocities were obtained in the apical 4-chamber view, with the sample volume placed at the mitral valve leaflet tips. Measurements included the transmitral early diastolic rapid filling (E-wave) and atrial contraction late filling (A-wave) velocities to calculate $\mathrm{E} / \mathrm{A}$ ratio, isovolumteric relaxation time (IVRT) and deceleration time (DT). For tissue Doppler imaging, the mitral annulus velocity was obtained with a $2 \mathrm{~mm}$ sample volume placed at the lateral side and septal side of the mitral annulus. Diastolic dysfunction was labelled according to the standard guidelines. Left ventricular overall ejection fraction (systolic function) was calculated by modified Simpson's method; and, LVEF $\geq 50 \%$ was considered as normal. All echocardiographic measurements were averaged over three consecutive cardiac cycles, measured by a single investigator blinded to all other variables

EXERCISE TESTING: It was performed at the LPS Institute of Cardiology. Patients were thoroughly evaluated clinically for fitness for exercise testing and patients with any contraindication to exercise testing were not given this test. Testing involved standard Bruce protocol with initial warm up phase. Heart rate, blood pressure \& ECG were taken before, during \& for $5 \mathrm{~min}$. after exercise at every one minute. Patient was asked to report any symptoms that he felt. Duration of exercise was also noted for every patient. Exercise test was equipped with Echocardiography \& phonocardiographic examination. 


\section{Estimation of Microalbuminuria:}

Microalbuminuria was established using Randoxkit.

Calculation of GFR- In adults, the best equation for estimating glomerular filtration rate (GFR) from serum creatinine is the isotope dilution mass spectrometry (IDMS)-traceable Modification of Diet in Renal Disease (MDRD) Study equation. This IDMS-traceable MDRD study equation calculator is for use with $S_{\mathrm{cr}}$ reported in $\mathrm{mg} / \mathrm{dL}$.

GFR $\left(\mathrm{mL} / \mathrm{min} / 1.73 \mathrm{~m}^{2}\right)=175 \times\left(\mathrm{S}_{\mathrm{cr}}\right)^{-1.154} \times(\text { Age })^{-}$ $0.203 \times(0.742$ if female $) \times$

(1.212 if African

American) (conventional units).

\section{Statistical Analysis}

The data was compiled and analysed using SPSS 17.0. Data was compared using percentages. Chi square test for proportions was applied to assess the association between categorical variables. Two tailed $p$-values $<0.05$ were considered significant.

\section{Results}

In the present study ninety cases of type 2 diabetes mellitus were taken and were divided into two groups:

Group - A: Patients of type II diabetes mellitus with signs and symptoms of cardiac disease $(\mathrm{n}=30)$

Group - B: Patients of type II diabetes mellitus without signs and symptoms of cardiac disease $(\mathrm{n}=60)$

These patients were also investigated for microalbuminuria and S.Creatinine for calculation of e GFR.

Out of ninety cases 58 cases were males and 32 cases were females. In both the groups males outnumbered the females as shown in the table given below:

Table I: Distribution of patients according to Sex

\begin{tabular}{|l|l|l|l|l|}
\hline \multirow{2}{*}{$\begin{array}{l}\text { Study } \\
\text { Group }\end{array}$} & \multicolumn{2}{|l|}{ Male } & \multicolumn{2}{l|}{ Female } \\
\cline { 2 - 5 } & $\begin{array}{l}\text { No. of } \\
\text { cases }\end{array}$ & Percentage & $\begin{array}{l}\text { No. } \\
\text { of } \\
\text { cases }\end{array}$ & Percentage \\
\hline GROUP A & 18 & 60.0 & 12 & 40.0 \\
\hline GROUP B & 40 & 66.6 & 20 & 33.3 \\
\hline
\end{tabular}

Graph 1: Distribution of patients according to Sex

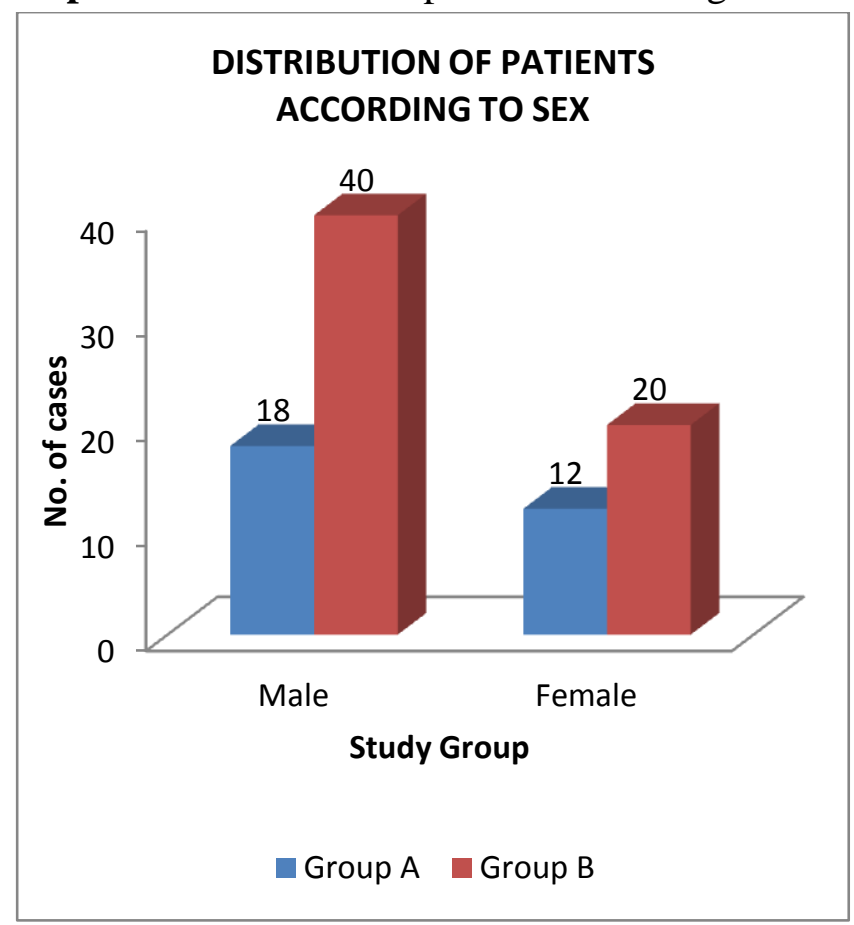

In our study majority of the patients in group A (type 2 DM with cardiac disease) were in the age group of $56-65$ years $(40 \%)$ followed by the age group of $66-75$ years $(33.3 \%)$ as shown in the given table -2 . In contrast to this majority of patients in group B (Type 2 DM without cardiac disease) were two decades younger than that of group A.

Table-2: Distribution of patients according to age

\begin{tabular}{|c|c|c|c|c|}
\hline \multirow{2}{*}{$\begin{array}{l}\text { Age } \\
\text { Group } \\
\text { (Yrs) }\end{array}$} & \multicolumn{2}{|l|}{ Group A } & \multicolumn{2}{|l|}{ Group B } \\
\hline & $\begin{array}{l}\text { No. of } \\
\text { cases }\end{array}$ & Percentage & $\begin{array}{l}\text { No. of } \\
\text { cases }\end{array}$ & Percentage \\
\hline $25-35$ & - & - & 04 & 06.6 \\
\hline $36-45$ & - & - & 24 & 40.0 \\
\hline $46-55$ & 08 & 26.6 & 20 & 33.3 \\
\hline $56-65$ & 12 & 40.0 & 12 & 20.0 \\
\hline $66-75$ & 10 & 33.3 & - & - \\
\hline
\end{tabular}

$40 \%$ patients in group B lie in between age group (36-45) followed by age group (46-55) years $(33.3 \%)$ 
Graph 2 - Distribution of patients according to age.

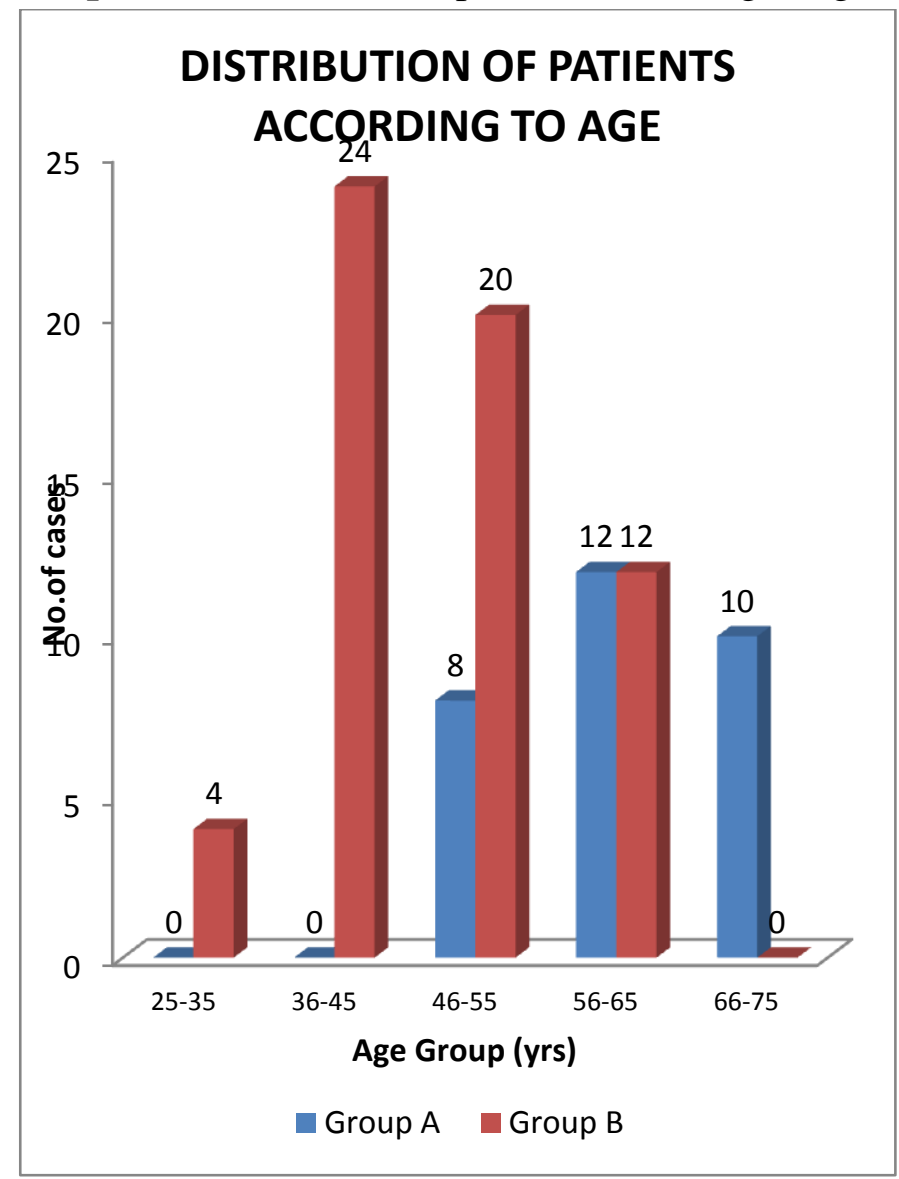

Table 3:- Distribution of Blood pressure

\begin{tabular}{|c|c|c|c|c|c|}
\hline Blood & \multicolumn{2}{|c|}{ Group A } & \multicolumn{2}{|c|}{ Group B } & probability \\
\hline $\begin{array}{l}>140 / 90 \\
\mathrm{~mm} / \mathrm{Hg}\end{array}$ & 20 & $66.6 \%$ & 16 & $26.6 \%$ & \\
\hline $\begin{array}{l}<140 / 90 \\
\mathrm{~mm} / \mathrm{Hg}\end{array}$ & 10 & $33.3 \%$ & 44 & $73.3 \%$ & $\mathrm{P}=0.001$ \\
\hline
\end{tabular}

In Group A $66.6 \%$ patients had increased blood pressure $>140 / 90 \mathrm{~mm} / \mathrm{Hg}$ and $33.3 \%$ patients had a blood pressure of $<140 / 90 \mathrm{~mm} / \mathrm{Hg}$. Group B 26.6 $\%$ patients had increased blood pressure $>140 / 90$ $\mathrm{mm} / \mathrm{Hg}$ and $73.3 \%$ patients had a blood pressure of $<140 / 90 \mathrm{~mm} / \mathrm{Hg}$.

The association between blood pressure and presence of cardiac manifestations was statistically significant.
Graph 3:- Distribution of Blood pressure

\section{DISTRIBUTION OF BLOOD PRESSURE}

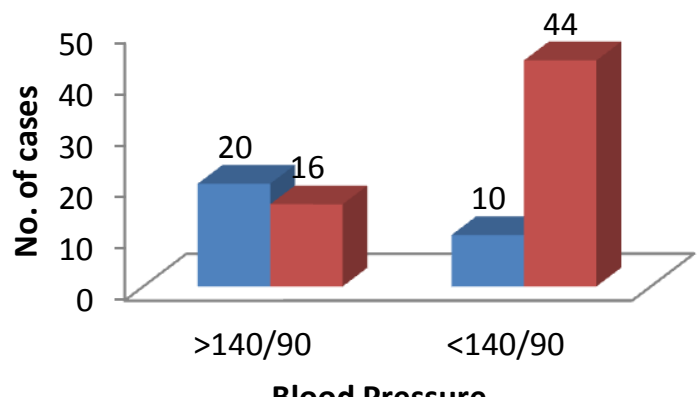

Blood Pressure

Group A Group B

Table 4 shows that in Group A $40 \%$ patients had higher cholesterol and $60 \%$ had a normal cholesterol level, In Group B 6.6\% patients had higher cholesterol and $93.3 \%$ had a normal cholesterol level.

In Group A 33.3\% patients had higher triglyceride levels and $66.6 \%$ had a normal triglyceride level whereas in Group B $13.3 \%$ patients had higher triglyceride levels and $86.6 \%$ had a normal triglyceride levels.

In Group A $46.6 \%$ patients had lower HDL levels and $53.3 \%$ had a normal HDL levels, In Group B $10 \%$ patients had lower HDL levels and $90 \%$ had a normal HDL levels.

Table 4:- Distribution of lipid profile

\begin{tabular}{|l|l|l|l|l|l|}
\hline \multicolumn{2}{|c|}{} & \multicolumn{2}{|c|}{ GROUP A } & \multicolumn{2}{l|}{ GROUP B } \\
\hline Cholesterol & $\begin{array}{l}>250 \\
\mathrm{mg} / \mathrm{dl}\end{array}$ & 12 & $40 \%$ & 4 & $6.6 \%$ \\
\cline { 2 - 6 } & $\begin{array}{l}<250 \\
\mathrm{mg} / \mathrm{dl}\end{array}$ & 18 & $60 \%$ & 56 & $93.3 \%$ \\
\hline \multirow{2}{*}{ TG } & $\begin{array}{l}>200 \\
\mathrm{mg} / \mathrm{dl}\end{array}$ & 10 & $33.3 \%$ & 8 & $13.3 \%$ \\
\cline { 2 - 7 } & $\begin{array}{l}<200 \\
\mathrm{mg} / \mathrm{dl}\end{array}$ & 20 & $66.6 \%$ & 52 & $86.6 \%$ \\
\hline \multirow{5}{*}{ HDL } & $\begin{array}{l}<40 \\
\mathrm{mg} / \mathrm{dl}\end{array}$ & 14 & $46.6 \%$ & 6 & $10 \%$ \\
\cline { 2 - 7 } & $\begin{array}{l}>40 \\
\mathrm{mg} / \mathrm{dl}\end{array}$ & 16 & $53.3 \%$ & 54 & $90 \%$ \\
\hline \multirow{2}{*}{ LDL } & $\begin{array}{l}>100 \\
\mathrm{mg} / \mathrm{dl}\end{array}$ & 16 & $53.3 \%$ & 12 & $20 \%$ \\
\cline { 2 - 6 } & $\begin{array}{l}<100 \\
\mathrm{mg} / \mathrm{dl}\end{array}$ & 14 & $46.6 \%$ & 48 & $80 \%$ \\
\hline
\end{tabular}


In Group A 53.3\% patients had higher LDL levels and $46.6 \%$ had a normal LDL levels, In Group B $20 \%$ patients had higher LDL levels and $80 \%$ had a normal LDL levels.

In Group A majority of patients (66.6\%) had duration of Type II DM more than 10 years whereas in Group B majority of patients (80.0\%) had duration of disease less than 10 years.

Table No. 5: Distribution of patients according to duration of diabetes mellitus

\begin{tabular}{|l|l|l|l|l|}
\hline $\begin{array}{l}\text { Duration } \\
\text { (yrs) }\end{array}$ & \multicolumn{2}{|l|}{ Group A } & \multicolumn{2}{l|}{ Group B } \\
\hline & $\begin{array}{l}\text { No. of } \\
\text { cases }\end{array}$ & Percentage & $\begin{array}{l}\text { No. of } \\
\text { cases }\end{array}$ & Percentage \\
\hline $\begin{array}{l}\text { Newly } \\
\text { detected }\end{array}$ & - & - & 08 & 13.3 \\
\hline $0-3$ & - & - & 20 & 33.3 \\
\hline $3-5$ & 02 & 06.6 & 16 & 26.6 \\
\hline $5-10$ & 08 & 26.6 & 04 & 06.6 \\
\hline $10-15$ & 12 & 40.0 & 12 & 20.0 \\
\hline$>15$ & 08 & 26.6 & - & - \\
\hline
\end{tabular}

Graph 4: Distribution of patients according to duration of diabetes mellitus.

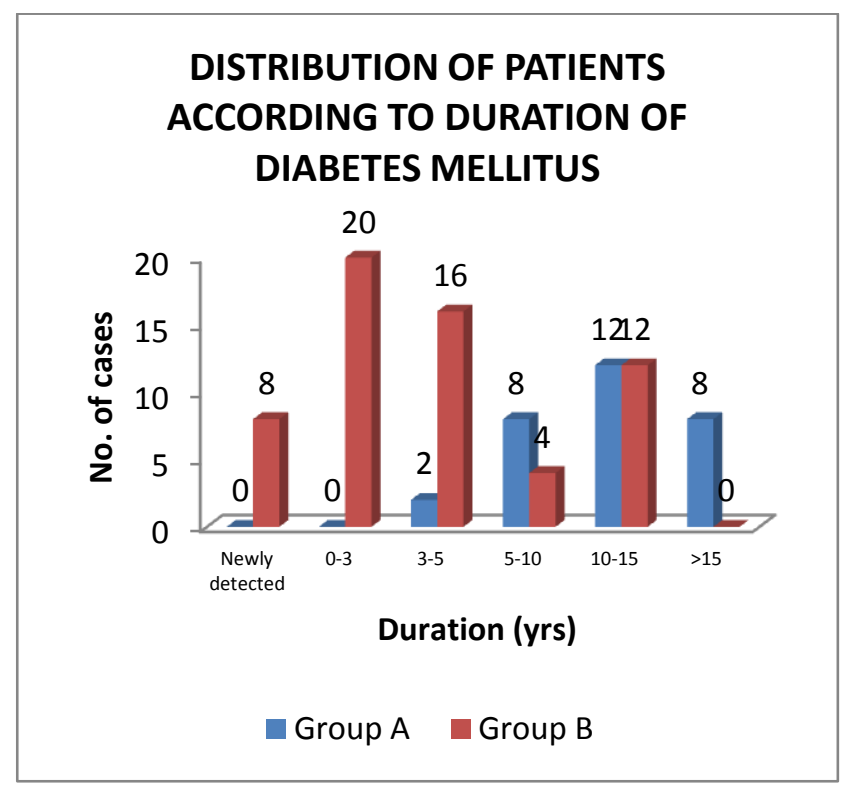

All the patients in group A had ECG changes whereas only $30 \%$ patients in Group B had ECG changes as given below.
Table 6: Distribution of patients according to ECG manifestations

\begin{tabular}{|l|l|l|l|l|}
\hline $\begin{array}{l}\text { ECG } \\
\text { Changes }\end{array}$ & \multicolumn{2}{|l|}{ Group A } & \multicolumn{2}{l|}{ Group B } \\
& $\begin{array}{l}\text { No. of } \\
\text { cases }\end{array}$ & Percentage & $\begin{array}{l}\text { No. of } \\
\text { cases }\end{array}$ & Percentage \\
\hline LVH & 10 & 33.3 & 06 & 10 \\
\hline LAE & 06 & 20.0 & - & - \\
\hline LAD & 12 & 40.0 & 12 & 20 \\
\hline RVH & 04 & 13.3 & - & - \\
\hline $\begin{array}{l}\text { ST- } \\
\text { Depression }\end{array}$ & 02 & 06.6 & - & - \\
\hline $\begin{array}{l}\text { ST- } \\
\text { Elevation }\end{array}$ & 02 & 06.6 & - & - \\
\hline
\end{tabular}

Above Table shows that in Group A maximum number of patients $(40 \%)$ had left axis deviation, $33.3 \%$ patients showed left ventricular hypertrophy, $20 \%$ patients demonstrated left atrial enlargement, $30.3 \%$ patients showed changes of right ventricular hypertrophy and only $6.6 \%$ patients showed ischemic changes in ECG.

In Group B only $10 \%$ patients showed left axis deviation and $20 \%$ patients showed left ventricular hypertrophy in ECG.

In this study maximum patients $(33.3 \%)$ in Group A had got a EF in between $56-60$ where as $20 \%$ patients had got EF in between $41-45 \%, 13.3 \%$ patients had got $\mathrm{EF}$ in between $51-55 \%, 6.6 \%$ patients had got EF in between $35-40 \%$ and $6.6 \%$ patients had got $\mathrm{EF}>60 \%$.

Table 7: Observations of ejection fraction at rest by echocardiography in study group

\begin{tabular}{|c|c|c|c|c|}
\hline \multirow{2}{*}{$\begin{array}{l}\text { Ejection } \\
\text { Fraction } \\
(\%)\end{array}$} & \multicolumn{2}{|l|}{ Group A } & \multicolumn{2}{|l|}{ Group B } \\
\hline & $\begin{array}{l}\text { No. of } \\
\text { cases }\end{array}$ & Percentage & $\begin{array}{l}\text { No. of } \\
\text { cases }\end{array}$ & Percentage \\
\hline $35-40$ & 02 & 06.6 & - & - \\
\hline $41-45$ & 06 & 20.0 & - & - \\
\hline $46-50$ & 04 & 13.3 & - & - \\
\hline $51-55$ & 06 & 20.0 & 12 & 20.0 \\
\hline $56-60$ & 10 & 33.3 & 36 & 53.3 \\
\hline$>60$ & 02 & 06.6 & 16 & 26.6 \\
\hline
\end{tabular}

In Group B none of the patients had EF $<50 \%$. Majority of the patients $(53.3 \%)$ had got EF in between $56-60 \%, 26.6 \%$ patients had got EF > $60 \%$ and $20 \%$ patients had got EF in between $51-$ $55 \%$. 


\section{JMSCR Vol||04||Issue||04||Page 9958-9970||April}

Majority of the patients $(80 \%)$ had E/A ratio decreased. This shows the diastolic dysfunction in these patients. $53.3 \%$ patients had increased end systolic volume of left ventricle, $40.0 \%$ patients had increased left ventricle internal diameter in systole, $33.3 \%$ patients had increased left ventricle internal diameter in diastole and $33.3 \%$ patients had increased left atrium dimension.

Table 8: Observations of Echocardiographic measurements in study group

\begin{tabular}{|c|c|c|c|c|c|c|}
\hline \multirow[t]{2}{*}{$\begin{array}{l}\text { Paramet } \\
\text { ers }\end{array}$} & \multirow{2}{*}{$\begin{array}{l}\text { No. of } \\
\text { cases } \\
\text { Size/Vol } \\
\text { ume }\end{array}$} & \multirow[t]{2}{*}{$\begin{array}{l}\text { Chang } \\
\text { es }\end{array}$} & $\begin{array}{l}\text { Grou } \\
\mathrm{p} \mathrm{A}\end{array}$ & & $\begin{array}{l}\text { Grou } \\
\text { p B }\end{array}$ & \\
\hline & & & $\begin{array}{l}\text { No. } \\
\text { of } \\
\text { cases }\end{array}$ & $\begin{array}{l}\text { Percen } \\
\text { tage }\end{array}$ & $\begin{array}{l}\text { No. } \\
\text { of } \\
\text { cases }\end{array}$ & $\begin{array}{l}\text { Percent } \\
\text { age }\end{array}$ \\
\hline LA & $\begin{array}{ll}12 & - \\
35 \mathrm{~mm} & \end{array}$ & $\begin{array}{l}\text { Increa } \\
\text { sed }\end{array}$ & 10 & 33.3 & - & - \\
\hline LVIDs & $\begin{array}{l}22 \\
43 \mathrm{~mm}\end{array}-$ & $\begin{array}{l}\text { Increa } \\
\text { sed }\end{array}$ & 12 & 40.0 & 04 & 06.6 \\
\hline LVIDd & $\begin{array}{ll}42 & - \\
60 \mathrm{~mm} & \end{array}$ & $\begin{array}{l}\text { Increa } \\
\text { sed }\end{array}$ & 10 & 33.3 & 04 & 06.6 \\
\hline $\begin{array}{l}\text { EDVL } \\
\mathrm{V}\end{array}$ & $\begin{array}{ll}85 & - \\
150 \mathrm{~mm}\end{array}$ & $\begin{array}{l}\text { Increa } \\
\text { sed }\end{array}$ & 08 & 26.6 & - & - \\
\hline ESVLV & $25-60 \mathrm{ml}$ & $\begin{array}{l}\text { Increa } \\
\text { sed }\end{array}$ & 16 & 53.3 & - & - \\
\hline $\begin{array}{l}\text { E/A } \\
\text { Ratio }\end{array}$ & - & $\begin{array}{l}\text { Decre } \\
\text { ased }\end{array}$ & 24 & 80.0 & 24 & 40.0 \\
\hline
\end{tabular}

Whereas In Group B 40.0\% patients had E/A ratio decreased. This shows the diastolic dysfunction in these patients. Only 6.6\% patients had increased left ventricle internal diameter in systole and diastole.

In Group A, $60.0 \%$ patients had positive stress test. Only $33.3 \%$ patients had achieved heart rate more than $85 \%$ of maximum heart rate. $60.0 \%$ faced chest discomfort during exercise. $26.6 \%$ patients got SBP below $120 \mathrm{~mm}$ of $\mathrm{Hg}$ during whole exercise and $13.3 \%$ patients could not be able to do exercise.

Table 9: Observation of Tread Mill testing in study group

\begin{tabular}{|l|l|l|l|l|}
\hline Observations & \multicolumn{2}{|l|}{ Group A } & \multicolumn{2}{l|}{ Group B } \\
\hline & $\begin{array}{l}\text { No. of } \\
\text { cases }\end{array}$ & $\begin{array}{l}\text { Percent } \\
\text { age }\end{array}$ & $\begin{array}{l}\text { No. } \\
\text { of } \\
\text { cases }\end{array}$ & $\begin{array}{l}\text { Percenta } \\
\text { ge }\end{array}$ \\
\hline Stress test positive & 18 & 60.0 & 04 & 06.6 \\
\hline $\begin{array}{l}\text { Cases who had } \\
>85 \% \text { of max } \\
\text { predicted HR }\end{array}$ & 10 & 33.3 & 60 & 100 \\
\hline
\end{tabular}

\begin{tabular}{|l|l|l|l|l|}
\hline $\begin{array}{l}\text { Patients having SBP } \\
<120 \text { mm of Hg }\end{array}$ & 08 & 26.6 & - & - \\
$\begin{array}{l}\text { during exercise or } \\
\text { fall in BP more than } \\
\text { 10mm of Hg from } \\
\text { resting B.P. }\end{array}$ & 18 & 60.0 & 04 & 06.6 \\
\hline Chest discomfort & 18 & 13.3 & - & - \\
\hline $\begin{array}{l}\text { Patients not able to } \\
\text { do exercise }\end{array}$ & 04 & & & \\
\hline
\end{tabular}

In Group B (without cardiac disease) 100\% patients achieved maximum heart rate more than $85 \%, 6.6 \%$ patients had positive stress test and $6.6 \%$ faced chest discomfort during exercise.

Table 10:- HbA1C level in both the groups

\begin{tabular}{|l|l|l|l|l|l|}
\hline $\begin{array}{l}\text { HbA1C } \\
\text { level }(\mathrm{g} \%)\end{array}$ & \multicolumn{2}{|l|}{ Group A } & \multicolumn{2}{l|}{ Group B } & Probability \\
\cline { 1 - 5 }$>6.5$ & 20 & $66.6 \%$ & 20 & $33.3 \%$ & \multirow{2}{*}{$\mathrm{P}=0.006$} \\
\hline$<6.5$ & 10 & $33.3 \%$ & 40 & $66.6 \%$ & \\
\hline
\end{tabular}

In Group A $66.6 \%$ had HbA1C level >6.5 and $33.3 \%$ patients had HbA1C level <6.5, In Group B $33.3 \%$ had HbA1C level $>6.5$ and $66.6 \%$ patiens had HbA1C level $<6.5$.

The association between $\mathrm{HbA} 1 \mathrm{C}$ level and presence of cardiac manifestations was statistically significant.

Graph 5:- HbA1C level in both the groups

\section{HbA1C LEVEL}

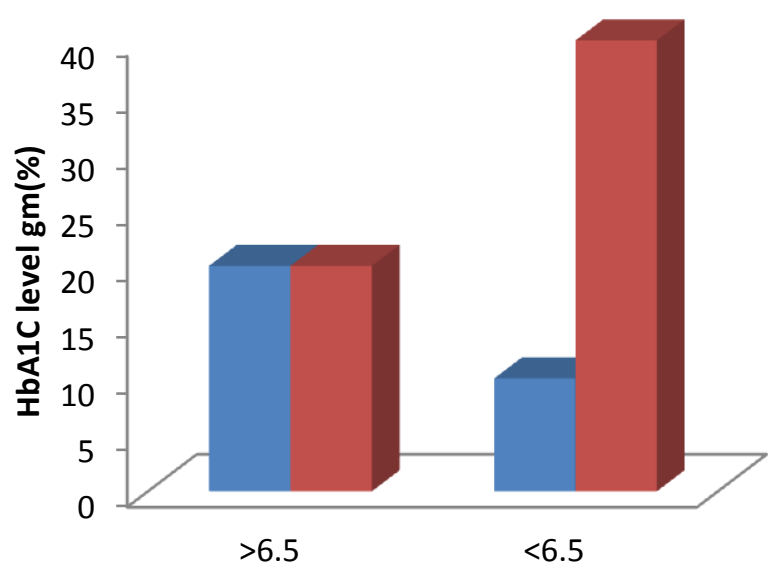

Axis Title

Group A Group B 


\section{JMSCR Vol||04||Issue||04||Page 9958-9970||April}

Table 11:- Albuminuria in relation to presence of cardiac manifestations

\begin{tabular}{|l|c|l|l|l|l|}
\hline $\begin{array}{l}\text { Urinary } \\
\text { albumin }\end{array}$ & \multicolumn{2}{|l|}{ Group A } & \multicolumn{2}{l|}{ Group B } & Probability \\
\hline$>30 \mathrm{mg} / \mathrm{dl}$ & 14 & $46.6 \%$ & 10 & $16.6 \%$ & $\mathrm{P}=0.005$ \\
\hline$<30 \mathrm{mg} / \mathrm{dl}$ & 16 & $53.3 \%$ & 50 & $83.3 \%$ & \\
\hline
\end{tabular}

In Group A 46.6\% patients had urinary albumin $>30 \mathrm{mg} / \mathrm{dl}$ and $53.3 \%$ patients had $<30 \mathrm{mg} / \mathrm{dl}$, In Group B $16.6 \%$ patients had urinary albumin $>30 \mathrm{mg} / \mathrm{dl}$ and $83.3 \%$ patients had $<30 \mathrm{mg} / \mathrm{dl}$.

The association between albuminuria and presence of cardiac manifestations was statistically significant.

Graph 6:- Albuminuria in relation to presence of cardiac manifestations

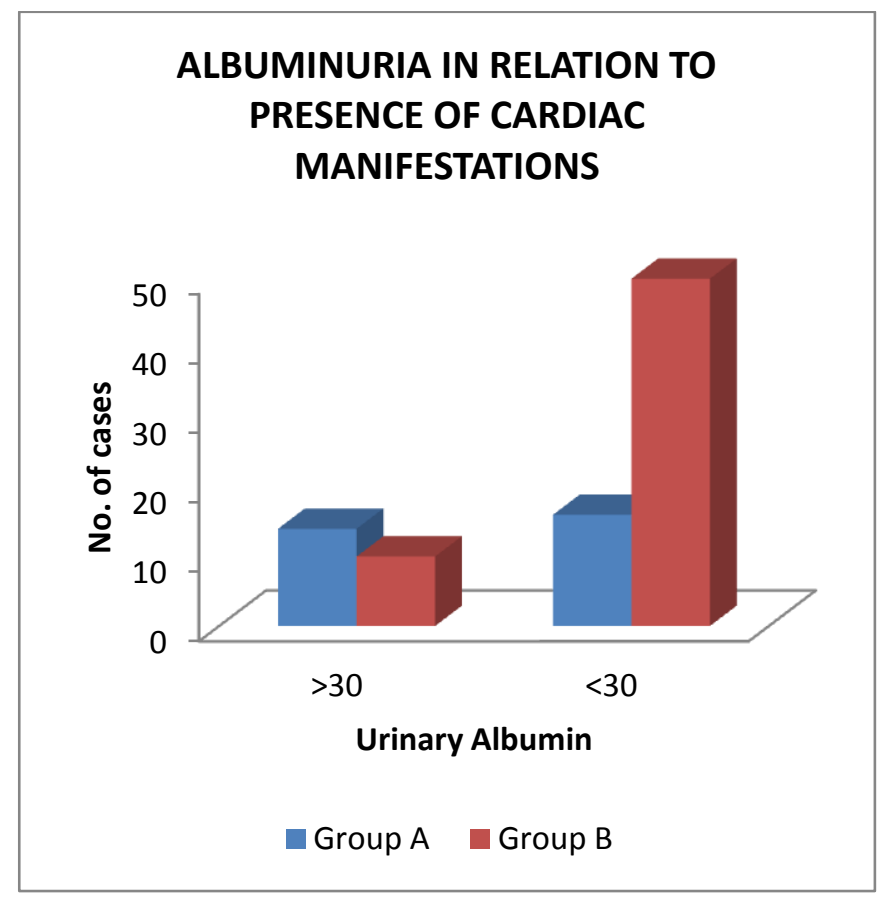

Table 12:- e GFR in relation to presence of cardiac manifestations

\begin{tabular}{|l|l|l|l|l|l|}
\hline e GFR & \multicolumn{2}{|l|}{ Group A } & \multicolumn{2}{l|}{ Group B } & \multicolumn{2}{l|}{$\begin{array}{l}\text { Probabil } \\
\text { ity }\end{array}$} \\
\hline$<60 \mathrm{ml} / \mathrm{min}$. & 6 & $20 \%$ & 8 & $13.3 \%$ & \\
\hline$>60 \mathrm{ml} / \mathrm{min}$. & 24 & $80 \%$ & 52 & $87.6 \%$ & $\begin{array}{l}\text { P } \\
0.607\end{array}$ \\
& & & & & \\
\hline
\end{tabular}

In group A $20 \%$ patients had prevalence of e GFR $<60 \mathrm{ml} / \mathrm{min}$ and Group B $13.3 \%$ patients had prevalence of e GFR $<60 \mathrm{ml} / \mathrm{min}$. Prevalence of e
GFR $<60 \mathrm{ml} / \mathrm{min}$ in diabetic patients in this study is $15.5 \%$. The association between e-GFR and presence of cardiac manifestations was not statistically significant.

Graph 7:- e GFR in relation to presence of cardiac manifestations

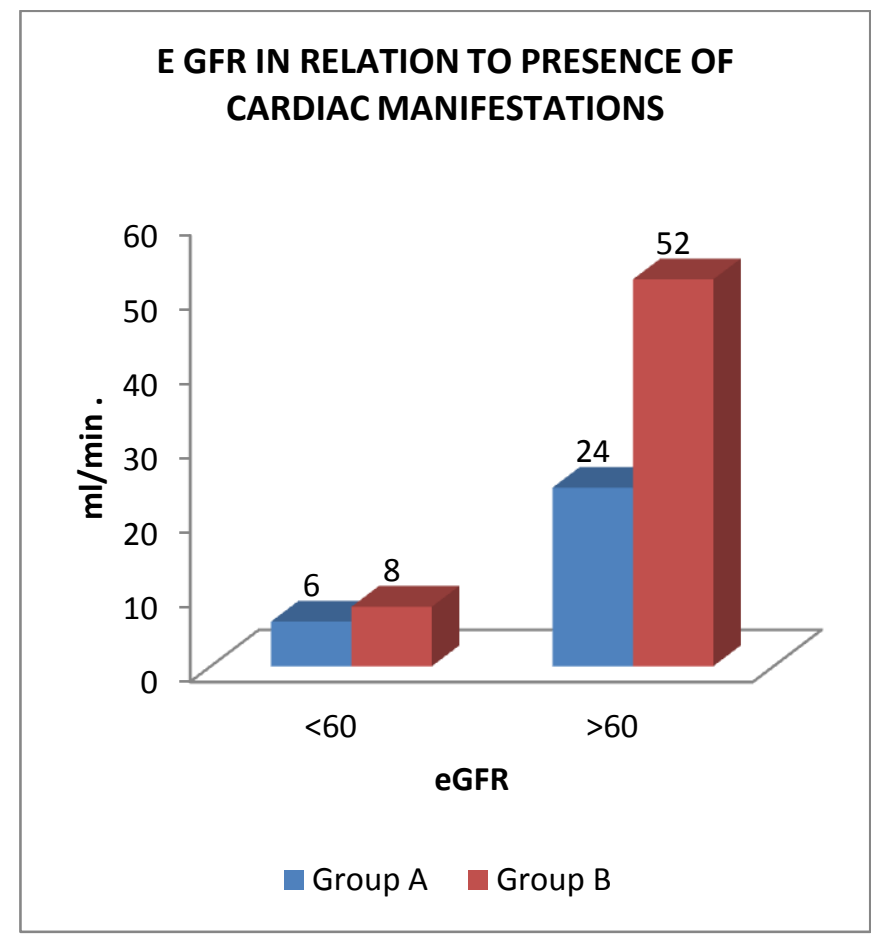

\section{DISCUSSION}

This study was conducted at LLR and associated hospitals, GSVM Medical College Kanpur. Ninety Patients were taken from General Medicine OPDs, Diabetes Clinics, and Medical wards of LLR Hospital employing appropriate inclusion and exclusion criteria. Their diabetic status was confirmed and they were categorized as per WHO 1985 criteria and grouped subsequently.

Group A: Patients of Type -2 Diabetes Mellitus with signs and symptoms of Cardiac disease [ $n=30]$ Group B: Patients of Type -2 Diabetes Mellitus without signs and symptoms of Cardiac disease [n=60]

\section{Age distribution}

In our study Maximum number of patients in group A lie in the age group 55-65 years while maximum number of group B patients lie in age group 45-55 years .So this shows that as the age increases in diabetics, diabetic patients become more vulnerable 
for cardiac diseases. Inoguchi $\mathrm{T}$, et al. (2000 JAN.) ${ }^{26}$ has found that elderly NIDDM patients (age over 60 years) had an extremely high prevalence (estimated 26.3\%) of silent myocardial ischemia become more vulnerable. This evidence suggests that early and intensive detection may be needed as a part of routine care for this group.

\section{Sex distribution}

Majority of patients were male in group A \& B, since this study drew patients coming to a tertiary level hospital, it was expected that male patients outnumber female patients. The pattern is distributed through the both groups. Slight dominance of male patients in number may be a reflection of their openness to visit hospital and may reflect sex distribution in employement, since many of patients visiting our hospital are public sector employees.

Framingham heart study (1974) - In this prospective study of 5000 individuals over an 18 year follow up period, the frequency of congestive heart failure was more than twice as high in diabetec men than in the nondiabetic cohort, while it was increased fivefold in diabetic women.

\section{Duration of disease}

Majority of patients $66.6 \%$ in group A had duration of diabetes mellitus more than 10 years. While in group B $70 \%$ patients had duration of diabetes mellitus less than 10 years.

Hamby et al. (1974) noted an increased incidence of diabetes in patients with idiopathic cardiomyopathy. He had done study on 73 patients in which he found the duration of diabetes in affected subjects were quite variable, ranging from less than 1 year to 11 years. $^{15}$

\section{Blood pressure}

In patients with cardiac disease $66.6 \%$ patients had increased blood pressure $>140 / 90 \mathrm{~mm} / \mathrm{Hg}$ and $33.3 \%$ patients had a blood pressure of $<140 / 90$ $\mathrm{mm} / \mathrm{Hg}$. Patients without cardiac disease $26.6 \%$ patients had increased blood pressure >140/90 $\mathrm{mm} / \mathrm{Hg}$ and $73.3 \%$ patients had a blood pressure of $<140 / 90 \mathrm{~mm} / \mathrm{Hg}$. Estacio RO et al. shows that use of antihypertensive in patients of diabetes decreases the risk of $\mathrm{CAD}^{17}$.

\section{Glycemic control}

In Group A $66.6 \%$ had HbA1C level >6.5 and $33.3 \%$ patients had HbA1C level <6.5, In Group B $33.3 \%$ had HbA1C level $>6.5$ and $66.6 \%$ patients had HbA1C level <6.5. The Honolulu Heart Study ${ }^{18}$, the Bedford Study ${ }^{19}$ and the Pathological Determinants of Atherosclerosis in Youth Study ${ }^{20}$ are some of the studies that have demonstrated the association of hyperglycemia with CAD. Reduction of CAD events with intensive glycemic control using insulin was shown in the randomized trial of insulin-glucose infusion followed by subcutaneous insulin treatment in diabetes patients with acute MI, which indirectly proves the association of hyperglycemia with CAD.

\section{Lipid profile}

In Group A 40\% patients had higher cholesterol and $60 \%$ had a normal cholesterol level, In Group B $6.6 \%$ patients had higher cholesterol and $93.3 \%$ had a normal cholesterol level. In Group A 33.3\% patients had higher triglyceride and $66.6 \%$ had a normal triglyceride level, In Group B $13.3 \%$ patients had higher triglyceride and $86.6 \%$ had a normal triglyceride level. In Group A $46.6 \%$ patients had lower HDL and 53.3\% had a normal HDL level, In Group B 10\% patients had lower HDL and $90 \%$ had a normal HDL level. In Group A $53.3 \%$ patients had higher LDL and $46.6 \%$ had a normal LDL level, In Group B 20\% patients had higher LDL and $80 \%$ had a normal LDL level.

Rajmohan $\mathrm{L}$, et $\mathrm{al}^{21}$. showed that the prevalence of CAD was significantly higher among patients with isolated hypercholesterolemia, isolated high LDL, and isolated low HDL cholesterol compared to normolipidemic individuals, but not in those with isolated hypertriglyceridemia.

\section{ECG manifestations in both groups}

Most of the patients in group A 33.3\% had got left ventricular hypertrophy. $40 \%$ patients in Group A had got left axis deviation. $13.3 \%$ patients had got right ventricular hypertrophy. $20 \%$ patients had got 
left atrial enlargement ECG shows the changes of cardiomyopathy in these patients. Only 13.3\% patients showed ischemic changes in resting ECG and only $13.3 \%$ developed MI showing ST elevation. In Group B only $10 \%$ patients had developed left ventricular hypertrophy and only $20 \%$ patients had developed left axis deviation.

\section{Echocardiographic Measurements}

In their pioneering study done on patients of cardiomyopathy, Robert Hamby and co-workers (1974) found a significantly increased association with diabetes ${ }^{15}$. They noted that LV end diastolic volume at rest was abnormally increased in diabetic patients. They did not index it to body surface area but this was statistically significant.

Zoneraich et $\mathrm{al}^{27} .1977$ found LV end systolic volume in diabetes without clinical heart disease to be higher than controls but this was not statistically significant.

Left ventricular end diastolic volume $(134 \pm 22.1 \mathrm{ml})$ in patients with signs and symptoms of cardiac disease was higher than patients without signs and symptoms of cardiac disease $(118 \pm 20.2 \mathrm{ml})$. This was statistically significant $(\mathrm{P}=0.032)$.

Left ventricular end systolic volume $(51.2 \pm 10.4 \mathrm{ml})$ in patients with signs and symptoms of cardiac disease was higher than patients without signs and symptoms of cardiac disease $(41.4 \pm 9.2 \mathrm{ml})$. This was statistically significant $(\mathrm{P}=0.032)$.

Shapiro et al. 1980in their work involving patients of all types of diabetes mellitus reported that diabetic patients had significantly increased LV end diastolic dimension and systolic dimension as compared to controls $(53+-9 \mathrm{~mm}, 45+-4 \mathrm{~mm}, \mathrm{P}<$ 0.001). As is obvious from table 7during systole left ventricular internal diameter was significantly higher in patients with signs and symptoms of cardiac disease than asymptomatic patients $(\mathrm{P}=$ 0.001 , highly significant) ${ }^{22,23}$.

During diastole left ventricular internal diameter was significantly higher in patients with signs and symptoms of cardiac disease than the patients without signs and symptoms $(\mathrm{P}=0.041)$.

Bouchard et al. 1989 studying both types of diabetics who were asymptomatic and normotensive but not necessarily free from CAD reported a decrease in E/A which was independent of age of patients or duration of diseases 24 .

Both type of diabetic patients Group A and Group B had diastolic dysfunction in most of the patients. $33.3 \%$ patients in Group A had got increased left atrial size. In Group B only $6.6 \%$ patients had increased left ventricular internal diameter in systole and diastole.

\section{Tread Mill Testing}

$60 \%$ patients of Group A had positive tread mill test that is development of $\geq 0.1 \mathrm{mv}(1 \mathrm{~mm})$ of $\mathrm{J}$ point depression measured from the PQ junction with relatively flat or flat slopping ST segment slope depressed $\geq 0.1 \mathrm{mv}, 80 \mathrm{msec}$. after the $\mathrm{J}$ point in three consecutive beats. While in Group B 6.6\% cases had got positive stress test results. In Group A only $33.3 \%$ patients had achieved maximum heart rate $>85 \%$ of predicted value. While in Group B $100 \%$ patients had achieved heart rate of $>85 \%$ of predicted value. In Group A $60 \%$ patients faced chest discomfort during exercise. While in Group B $6.6 \%$ patients had faced chest discomfort during exercise. In Group A $26.6 \%$ patients had got systolic blood pressure below $120 \mathrm{~mm} \mathrm{Hg}$ during exercise or fall in blood pressure $>10 \mathrm{~mm}$ of $\mathrm{Hg}$ from normal resting blood pressure during exercise. This suggests that their stroke volume was so low that they were not able to achieve systolic blood pressure more than $120 \mathrm{~mm}$ of $\mathrm{Hg}$. While in Group B every patient had achieved blood pressure > $120 \mathrm{~mm}$ of $\mathrm{Hg}$. Positive stress test implies that patients had got significant coronary artery disease.

Sasaki A,(1999 APRIL) ${ }^{28}$ had found the frequency of IHD in the group $(n=22,36.4)$ with microalbuminuria that was significantly $(p<0.03)$ higher than those $(n=38,10.5 \%)$ with normoalbuminuria. We concluded that the measurement of urinary albumin is important when approaching diabetic macroangiopathy.

\section{Ejection Fraction}

In Group A majority of patients (60\%) had ejection fraction less than 55\%. While in Group B $80 \%$ patients had got ejection fraction more than $55 \%$. Ejection fraction was lowered in Group A because of impaired systolic performance of the left 
ventricle due to cardiomyopathy. Cardiomyopathy can be because of two reasons: (i) Ischemic (ii) Diabetes alone can cause interstitial fibrosis and leads to cardiomyopathy without atherosclerosis.

Hamby et al. (1974) ${ }^{15}$ noted that diabetics had lower ejection fraction at rest but their work includes only 12 patients including the patients of coronary artery disease. Zoneraich et $\mathrm{al}^{27}$ (1977) observed lower ejection fraction in diabetic patients but this difference was not significant.

In a controlled study done by Senevitarne et al. (1977), it was shown that diabetic patients with evidence of microangiopathy had significantly lower fractional shortening as compared to control group. Shapiro et al. (1980) ${ }^{22}$ \& Abenovolie T al. $(1981)^{\mathbf{2 5}}$ reported of similar findings.

\section{Microalbuminuria}

Sasaki A, et al.(1999 APRIL) ${ }^{28}$ had found the frequency of IHD in the group $(n=22,36.4)$ with microalbuminuria was significant $(\mathrm{p}<0.03)$ higher than those $(n=38,10.5 \%)$ with normoalbuminuria.

In Group A $46.6 \%$ patients had urinary albumin $>30 \mathrm{mg} / \mathrm{dl}$ and $53.3 \%$ patients had $<30 \mathrm{mg} / \mathrm{dl}$, In Group B $16.6 \%$ patients had urinary albumin $>30 \mathrm{mg} / \mathrm{dl}$ and $83.3 \%$ patients had $<30 \mathrm{mg} / \mathrm{dl}$

\section{e GFR}

In group A $20 \%$ patients had prevalence of e GFR $<60 \mathrm{ml} / \mathrm{min}$ and Group B $13.3 \%$ patients had prevalence of e GFR $<60 \mathrm{ml} / \mathrm{min}$. Prevalence of e GFR $<60 \mathrm{ml} / \mathrm{min}$ in diabetic patients in this study is $15.5 \%$. The association between e-GFR and presence of cardiac manifestations was not statistically significant.

\section{CONCLUSION}

From our study we conclude that majority of the patients having signs and symptoms of cardiac disease lie in elderly age group i.e. more than 60 years. While majority of the patients not having signs and symptoms of cardiac disease lie in age group less than 50 years.

In both type of diabetics majority of patients were male genders. That can only be explained by their more openness to visit hospitals.
$66.6 \%$ patients of having signs and symptoms of cardiac disease had duration of diabetes mellitus more than 10 years. While $80 \%$ of patients without having any feature of cardiac disease had duration less than 10 years.

In ECG, patients with signs and symptoms of cardiac disease showed left ventricular hypertrophy in $33.3 \%$ cases but only by seeing left ventricular hypertrophy in ECG it is very difficult to comment on dilatation or hypertrophy. $6.6 \%$ patients showed ischemic changes (i.e. ST depression) in resting ECG.

Both groups showed diastolic dysfunction in echocardiography.

Left ventricular internal diameter during systole in patients with signs and symptoms of cardiac disease $(38.26 \pm 8.4)$ was greater than patients without signs and symptoms of cardiac disease $(30.4 \pm 5.7 \mathrm{~mm})$. This difference was statistically significant $(\mathrm{p}=0.001)$.

Left ventricular internal diameter during diastole in patients with signs and symptoms of cardiac disease $(55 \pm 9.7 \mathrm{~mm})$ was greater than patients without signs and symptoms of cardiac disease (50 \pm $5.4 \mathrm{~mm})$. This difference was statistically significant $(\mathrm{p}=0.041)$.

End systolic volume of left ventricle was higher in patients with signs and symptoms of cardiac disease $(51.2 \pm 10.4 \mathrm{ml})$ than patients without signs and symptoms of cardiac disease $(41.4 \pm 9.2 \mathrm{ml})$. This difference was statistically significant $(\mathrm{p}=0.011)$.

End diastolic volume of left ventricle was higher in patients with signs and symptoms of cardiac disease $(134 \pm 22.1 \mathrm{ml})$ than patients without signs and symptoms of cardiac disease $(118 \pm 20.2 \mathrm{ml})$. This difference was statistically significant $(\mathrm{p}=0.03)$.

13 patients with signs and symptoms of cardiac disease had undergone tread mill testing. This test was positive in $60 \%$ cases. $13.3 \%$ patients were not able to do exercise because of some contraindications. $26.6 \%$ patients had systolic blood pressure below $120 \mathrm{mmHg}$ during whole exercise in patients with signs and symptoms of cardiac disease.

$60 \%$ patients with cardiac disease had ejection fraction below $50 \%$ whereas only $20 \%$ patients 
without cardiac disease had ejection fraction between $51-55 \%$ and none below $50 \%$.

Blood pressure was higher in patients with signs and symptoms of cardiac disease than patients without signs and symptoms of cardiac disease. The association between blood pressure and presence of cardiac manifestations was statistically significant $(\mathrm{p}=0.001)$.

HbA1C level was higher in patients with signs and symptoms of cardiac disease than patients without signs and symptoms of cardiac disease. The association between $\mathrm{HbA} 1 \mathrm{C}$ level and presence of cardiac manifestations was statistically significant $(\mathrm{p}=0.006)$.

e $\operatorname{GFR}(<60 \mathrm{ml} / \mathrm{min})$ was higher in patients with signs and symptoms of cardiac disease than patients without signs and symptoms of cardiac disease. The association between e GFR and presence of cardiac manifestations was statistically not significant $(\mathrm{p}=0.607)$.

Albuminuria was higher in patients with signs and symptoms of cardiac disease than patients without signs and symptoms of cardiac disease. The association between Albuminuria and presence of cardiac manifestations was statistically significant $(\mathrm{p}=0.005)$.

So from this we conclude that patients of type 2 diabetes mellitus without cardiac disease (asymptomatic) do have left ventricular diastolic function as well as left ventricular systolic dysfunction and this dysfunction increases with duration of diabetes mellitus, higher blood pressure, higher Hba1c levels and presence of albuminuria but not with eGFR. Strict watch and control of these parameters will help to delay the onset of cardiac disease in asymptomatic patients of type 2 diabetes mellitus.

\section{REFERENCES}

1. Kleinman JC, Donahue RP, Harris MI, Finucane FF, Madans JH, Brock DB. Mortality among diabetes in a national sample. Am J Epidemiol 1988;128:389-401.

2. Rask-Madsen $C$ et al. Mechanisms of disease: Endothelial dysfunction in insulin resistance and diabetes. Nat Clin Pract Endocrinol Metab. 2007;3:46-56.

3. Khera A et al. Management of diabetic dyslipidemia: Need for reappraisal of the goals. Am J Cardiovasc Drugs. 2005;5:83.

4. Libby $P$ et al. Inflammation in diabetes mellitus: Role of peroxisome proliferatoractivated receptor-alpha and peroxisome proliferator-activated receptor-gamma agonists. Am J Cardiol. 2007;99:27B-40.

5. Mathewkutty $S$ et al. Platelet perturbations in diabetes: Implications for cardiovascular disease risk and treatment. Expert Rev CardiovascTher. 2009;7:541-9.

6. Shindler DM, Kostis JB, Yusuf S, Quinones MA, Pitt B, Stewart D, et al. Diabetes mellitus, a predictor of morbidity and mortality in the Studies of Left Ventricular Dysfunction (SOLVD) Trials and Registry. Am J Cardiol 1996;77(11):1017-20.

7. Bertoni AG, Tsai A, Kasper EK, Brancati FL. Diabetes and idiopathic cardiomyopathy: a nationwide case-control study. Diabetes Care 2003;26(10):2791-5.

8. Williams SB, Cusco JA, Roddy MA, Johnstone MT, Creager MA. Impaired nitric oxide-mediated vasodilation in patients with non-insulin dependent diabetes mellitus. J Am Coll Cardiol 1996; 27:567-74.

9. Williams SB, Goldfine AB, Timimi FK, Ting HH, Roddy MA, Simonson DC, et al. Acute hyperglycemia attenuates endothelium-dependent vasodilation in humans in vivo. Circulation 1998; 97:1695701.

10. Solang I, Malmberg K, Ryden I. Diabetes Mellitus and congestive heart failure. Eur Heart J 1999; 20:789-95.

11. Rubler S, Dlugash J, Yuceoglu YZ, Kumral T, Branwood AW, Grishman A. New type of cardiomyopathy associated with diabetic glomerulosclerosis. Am J Cardiol 1972;30(6):595-602.

12. Fein, F.S., Sonnenblick, EH: Diabetic Cardiomyopathy. Progcardiovasc Dis 1985, $255-70$. 
13. Kazik A, Wilczek K, Poloński L. Management of diastolic heart failure. Cardiol J. 2010;17:558-65.

14. Fang ZY, Prins JB, Marwick TH. Diabetic cardiomyopathy: evidence, mechanisms, and therapeutic implications. Endocr Rev 2004; 25(4):543-67.

15. Hamby ,R,I. ; Zoneraich, S., Sherma, L. et al : Cardiomyopathy, JAMA 1974, 229: 1749.- 54.

16. Vijan $S$, Hayward RA et al. Treatment of hypertension in type 2 diabetes mellitus: Blood pressure goals, choice of agents, and setting priorities in diabetes care. Ann Intern Med 2003; 138:59.

17. Estacio $R O$ et al. The effect of nisoldipine as compared with enalapril on cardiovascular outcomes in patients with non-insulindependent diabetes and hypertension. $\mathrm{N}$ Engl J Med. 1998;338(10):645-652.

18. Donahue et al. Postchallenge glucose concentration and coronary heart disease in men of Japanese ancestry. Honolulu Heart Program. Diabetes. 1987;36(6):689-692.

19. Jarrett RJ et al. The Bedford Survey: ten year mortality rates in newly diagnosed diabetics, borderline diabetics and normoglycaemic controls and risk indices for coronary heart disease in borderline diabetics. Diabetologia. 1982;22(2):79-84.

20. McGill HC Jr et al, Strong JP.Relation of glycohemoglobin and adiposity to atherosclerosis in youth. Pathological Determinants of Atherosclerosis in Youth (PADY) Research Group. Arterioscler ThrombVasc Biol. 1995;15(4):431-440.

21. Rajmohan L, et al. Association between isolated hypercholesterolemia, isolated hypertriglycerideia and coronary artery disease in South Indian type 2 diabetic patients. Indian Heart J. 2000;52(4):400406.

22. Shapiro, L.M., Leatherdale, BA, Mackinnon, J; Fletcher, R.F. • Left Ventricular function in diabetes mellitus.II relation between clinical features and left ventricular function.Br Heart J, 1981, Vol. 45, P 129 - 32.

23. Shapiro IX,N, Leatherdale, B.A. ; Coyne , M. E. et al . Prospective study of heart disease in untreated maturity onset diabetics.Br Heart J. 1982, 47:439-44,

24. Bouchard, A., :Nancy Sanz, MD, et al. : Noninvasive Assessment of Cardiomyopathy in normotensive diabetic patients between $20 \& 50$ years old. The Am. J. of Medicine, 1989, Vol. 87, P 160.

25. Abenavoli, T.,:Rubler, S. etal, Exercise Testing vvith Myocardial Scintigraphyj.n a symptomatic Diabetic Males. Circulation, 1981, Vol., 63, P 54.

26. Inoguchi T, Yamashita T, Umeda F, Mihara $\mathrm{H}$, Nakagaki O, Takada K, Kawano $T$, Murao H, Doi T, Nawata H. High incidence of silent myocardial ischemia in elderly patients with non insulin-dependent diabetes mellitus. Diabetes Res Clin Pract. 2000 Jan;47(1):37-44.PMID: 10660219

27. Zoneraich S. Left ventricular diastolic dysfunction evaluated by Doppler echocardiography in patients with diabetes mellitus. Am J Cardiol. 1989 Nov 1;64(16):1037-8. PubMed PMID: 2816735.

28. Sasaki A, Oikawa S, Toyota T. Microalbuminuria is closely related to diabetic macroangiopathy. Diabetes Res Clin Pract. 1999 Apr;44(1):35-40. PubMed PMID: 10414938. 